\title{
Perbedaan tingkat kecemasan pada orang tua penderita celah bibir dan langit-langit yang belum dan telah dioperasi
}

\author{
Sarasti Laksmi Anindita ${ }^{1}$, Kirana Lina Gunawan ${ }^{1}$, Indra Hadikrishna ${ }^{1}$ \\ ${ }^{1}$ Departemen Bedah Mulut, Fakultas Kedokteran Gigi, Universitas Padjadjaran, Indonesia \\ *Korespondensi : Sarasti14001@mail.unpad.ac.id
}

\begin{abstract}
ABSTRAK
Pendahuluan: Orang tua dengan anak penderita celah bibir dan langit-langit yang akan dioperasi sering mengalami kecemasan, baik penderita celah bibir dan langit-langit yang belum dan telah dioperasi.Tujuan penelitian menganalisis perbedaan tingkat kecemasan yang terjadi pada orang tua dari anak penderita celah bibir dan langit-langit baik yang belum maupun telah dilakukan operasi. Metode: Penelitian ini merupakan studi komparatif dengan jumlah responden 17 orang tua dari penderita yang belum dioperasi dan 13 orang tua dari penderita yang telah dioperasi. Teknik pengambilan sampel menggunakan purposive sampling dengan instrumen penelitian berupa kuesioner Stait Trait Anxiety Inventory (STAI). Hasil: State dan trait anxiety berada dalam kategori sedang. State anxiety lebih tinggi dibandingkan dengan trait anxiety. Analisis perbandingan masing-masing state dan trait pada kedua kelompok menunjukkan $\mathrm{H}_{0}$ diterima $(\mathrm{p}>0,05)$. Kecemasan dapat disebabkan oleh beberapa faktor seperti jenis kelamin, usia, pendidikan terakhir, status ekonomi, dan pekerjaan. Simpulan: tidak terdapat perbedaan signifikan antara orang tua dari penderita celah bibir dan langit-langit yang belum dioperasi dan orang tua dari penderita celah bibir dan langit-langit yang telah dioperasi.

Kata kunci : Celah bibir dan langit-langit, kecemasan
\end{abstract}

Kata kunci: Celah bibir dan langit langit, kecemasan, orangtua

\section{Difference level of anxiety on parents of cleft lip and palate patient who have not and have been operated}

\section{ABSTRACT}

Introduction: Parents of children with cleft lips and palate will often feels anxiety, either cleft lip and palate which have not been operated or parents of patients with cleft lip and palate which have been operated. The aim of the study was to analyze differences in the level of anxiety that occurs in parents of children with lip and palate patients who have not or have not been operated on. Methods: This study is a comparative study with the number of respondents 17 parents of patients who have not surgery and 13 parents of patients who have surgery. Sampling technique using purposive sampling with research instrument in the form of Stait Trait Anxiety Inventory (STAI) questionnaire. Results: State and trait anxiety for both groups in the medium category. State anxiety is higher than trait anxiety. Comparative analysis of each state and trait in both groups showed $H_{0}$ received ( $\left.p>0.05\right)$. Anxiety can be caused by several factors sexes, age, school education, economic status, and work. Conclusion: There aren't significant difference between parents of patients with cleft lip and palate which have not been operated and parents of patients with cleft lip and palate which have been operated. 


\section{PENDAHULUAN}

Orang tua ingin anak yang sempurna, tidak memiliki kelainan baik fisik maupun psikis. ${ }^{1}$ Kelainan fisik yang dialami oleh anak salah satunya anomali kongenital. Menurut WHO, anomali kongenital dapat didefinisikan sebagai anomali struktural atau fungsional (misalnya gangguan metabolisme) yang terjadi selama kehidupan intrauterin dan dapat diidentifikasi secara prenatal, saat lahir atau di kemudian hari, contohnya adalah celah bibir dan/ atau langit-langit. ${ }^{2}$ Celah bibir dan langit-langit adalah suatu kelainan kongenital yang disebabkan tidak menyatunya sebagian atau seluruh prominensia maksilaris dengan prominensia nasalis mediana di satu atau kedua sisi. ${ }^{3}$ Celah bibir dan langitlangit menganggu proses yang terjadi dalam mulut. Perawatan yang komprehensif perlu dilakukan untuk memperbaiki masalah yang dialami oleh penderita, salah satu tindakan yang dilakukan adalah operasi yang dapat menyebabkan kecemasan yang dialami oleh anak maupun orang tua yang mendampingi operasi. Orang tua dengan anak yang akan dioperasi sering mengalami kecemasan karena sebagian besar orang tua masih berpikir bahwa operasi merupakan salah satu prosedur yang memiliki risiko tinggi pada anak mereka. ${ }^{4}$

Orang tua yang menunjukkan kegelisahan sebelum operasi, anak dapat menangkap emosional yang dialami orang tua dan mulai menunjukkan perilaku dan reaksi yang serupa. ${ }^{4}$ Kecemasan orang tua pada anak pre operasi salah satunya dipengaruhi oleh pengalaman individu. ${ }^{5}$ Kecemasan yang secara psikologis dialami orang tua dapat berdampak pada suasana hati dan komunikasi, orang tua akan sulit untuk melakukan komunikasi dan menerima informasi umum. .,7 $^{6}$

Berdasarkan latar belakang di atas, penulis tertarik untuk melakukan penelitian yang bertujuan untuk menganalisis perbedaan tingkat kecemasan yang terjadi pada orang tua dari anak penderita celah bibir dan langit-langit baik yang belum maupun telah dilakukan operasi.

\section{METODE}

Penelitian yang akan dilakukan adalah studi komparatif. Penelitian menggunakan statistik inferensial untuk memperlihatkan perbandingan mengenai keadaan atau kondisi fakta dari suatu populasi. Populasi yang diambil adalah orang tua penderita celah bibir dan langit-langit, ayah atau ibu, baik yang anaknya belum maupun telah dioperasi di Cleft Center RSGM Fakultas Kedokteran Gigi Universitas Padjadjaran. Teknik sampling yang digunakan dalam penelitian ini adalah purposive sampling. Alat pengukur data menggunakan instrumen penelitian dalam hal ini berupa kuesioner. Kuesioner yang digunakan adalah kuesioner STAI (State Trait Anxiety Inventory) yang di dalamnya terdiri dari dua bagian. Bagian pertama yaitu state anxiety (form $\mathrm{y}-1$ ) berisi 20 pertanyaan yang menunjukkan perasaan responden saat ini dan bagian kedua yaitu trait anxiety (form y-2) berisi 20 pertanyaan yang menunjukkan perasaan responden pada umumnya. Total skor dari masing-masing kuesioner minimum 20 dan maksimum 80, dimana kecemasan yang besar ditunjukan dengan skor yang lebih tinggi. Penelitian ini dilakukan pada Desember 2017 sampai Februari 2018 di Cleft Center RSGM FKG Unpad. Penelitian ini menggunakan rancangan penelitian komparasi untuk mengetahui perbedaan variabel yang dihipotesiskan. Oleh karena itu, uji statistik menggunakan Mann Whitney.

\section{HASIL}

Kelompok orang tua penderita yang baru pertama kali dioperasi diberi keterangan dengan huruf A dan kelompok orang tua penderita dengan riwayat operasi sebelumnya diberi keterangan dengan huruf B.

Tabel 1 Pembagian kategori state dan trait pada kelompok A dan B

\begin{tabular}{|c|c|c|c|c|c|c|c|c|}
\hline \multirow{3}{*}{ Kategori } & \multicolumn{4}{|c|}{ State } & \multicolumn{4}{|c|}{ Trait } \\
\hline & \multicolumn{2}{|c|}{ A } & \multicolumn{2}{|c|}{ B } & \multicolumn{2}{|c|}{ A } & \multicolumn{2}{|c|}{ B } \\
\hline & $\mathbf{n}$ & $\%$ & $\mathbf{N}$ & $\%$ & $\mathbf{N}$ & $\%$ & $\mathbf{N}$ & $\%$ \\
\hline Rendah & 3 & $17,647 \%$ & 1 & $7,692 \%$ & 8 & $47,059 \%$ & 6 & $46,153 \%$ \\
\hline Sedang & 8 & $47,058 \%$ & 9 & $69,230 \%$ & 9 & $52,941 \%$ & 7 & $53,846 \%$ \\
\hline Tinggi & 6 & $35,294 \%$ & 3 & $23,076 \%$ & 0 & 0 & 0 & 0 \\
\hline
\end{tabular}

sedangkan trait anxiety menunjukkan hasil tertinggi pada kategori sedang dengan $n=9$ dan 52,941 untuk kelompok A dan n=7 dan 53,846 untuk kelompok B.
State anxiety menunjukkan hasil tertinggi pada kategori sedang dengan $\mathrm{n}=8$ dan 47,058 untuk kelompok A dan n=9 dan 69,230 untuk kelompok B, 


\begin{tabular}{ccc}
\hline & $\begin{array}{c}\text { Tabel 2. Uji non-parametrik mann whitney state dan trait } \\
\text { anxiety kelompok A dan B }\end{array}$ & Trait \\
\hline Mann-Whitney U & State & 104,000 \\
Wilcoxon W & 102,500 & 257,000 \\
Z & 193,500 &,- 272 \\
Asymp. Sig. (2-tailed) &,- 335 &, 785 \\
Exact Sig. [2*(1-tailed Sig.)] &, 737 &, $805 \mathrm{~b}$ \\
\hline
\end{tabular}

Tabel 3. Rata-rata state dan trait anxiety berdasarkan jenis kelamin

\begin{tabular}{lllll}
\hline & \multicolumn{3}{l}{ Perempuan $(\mathbf{n}=\mathbf{2 4})$} & Laki-laki $(\mathbf{n}=\mathbf{6})$ \\
\cline { 2 - 5 } & State & Trait & State & Trait \\
\hline $\bar{X}$ & 51,54167 & 41,29167 & 47,5 & 38,5 \\
\hline
\end{tabular}

Tabel 4. Rata-rata state dan trait anxiety berdasarkan usia

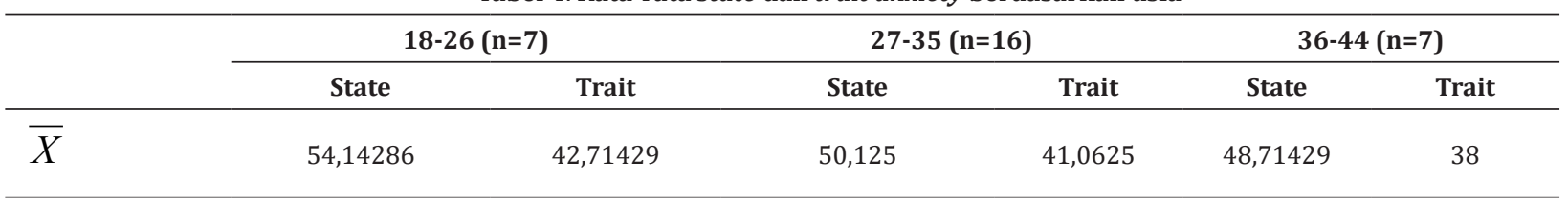

Rata-rata state berdasarkan usia secara berurutan memiliki hasil dari terendah ke tertinggi adalah usia 36-44 tahun (48,71429), usia 27-35 tahun $(50,125)$, dan usia $18-26$ tahun $(54,14286)$.

Hasil rata-rata state pada perempuan adalah 51,54167 lebih tinggi dibanding dengan laki-laki yakni 47,5. Responden pada penelitian ini lebih banyak pada perempuan $(n=24)$ dibanding dengan laki-laki $(n=6)$. Rata-rata hasil state berdasarkan status ekonomi diurutkan dari terendah ke tertinggi yaitu lebih dari Rp 2.000.000,00 (47,36364), Rp 1.000.000,00 - Rp 2.000.000,00 (51,09091), Rp 500.000,00 - Rp $1.000 .000,00$ (52), dan kurang dari Rp 500.000,00 $(56,6)$. Hasil tertinggi pada kelompok penghasilan kurang dari Rp 500.000,00.

Tabel 5. Rata-rata state dan trait anxiety berdasarkan status ekonomi

\begin{tabular}{|c|c|c|c|c|c|c|c|c|}
\hline & \multicolumn{2}{|c|}{$\begin{array}{c}<\operatorname{Rp~500.000} \\
(n=5)\end{array}$} & \multicolumn{2}{|c|}{$\begin{array}{c}\text { Rp 500.000 - Rp } 1.000 .000 \\
(n=3)\end{array}$} & \multicolumn{2}{|c|}{$\begin{array}{l}\text { Rp 1.000.000 - Rp } \\
2.000 .000(n=11)\end{array}$} & \multicolumn{2}{|c|}{$>\operatorname{Rp} 2.000 .000(n=11)$} \\
\hline & State & Trait & State & Trait & State & Trait & State & Trait \\
\hline $\bar{X}$ & 56,6 & 48,4 & 52 & 46,33333 & 51,09091 & 37 & 47,36364 & 39,45455 \\
\hline
\end{tabular}

Tabel 6. Rata-rata state dan trait anxiety berdasarkan pekerjaan

\begin{tabular}{ccccccccccc}
\hline & \multicolumn{2}{c}{ IRT $(\mathrm{n}=22)$} & \multicolumn{2}{c}{ Buruh $(\mathrm{n}=4)$} & \multicolumn{2}{c}{ Wirausaha $(\mathrm{n}=2)$} & \multicolumn{2}{c}{ Karyawan $(\mathrm{n}=1)$} & \multicolumn{2}{c}{ PN $(\mathrm{n}=1)$} \\
\cline { 2 - 11 } & State & Trait & State & Trait & State & Trait & State & Trait & State & Trait \\
\hline $\bar{X}$ & \multirow{2}{*}{51,727} & 41,818 & 46 & 38 & 45 & 39 & 68 & 38 & 42 & 34 \\
\hline
\end{tabular}

Hasil state berdasarkan pekerjaan menunjukkan urutan rata-rata dari terendah ke tertinggi yaitu pegawai negeri (42), wirausaha (45), buruh (46), ibu rumah tangga (51,727), dan karyawan (68). Responden terbanyak adalah ibu rumah tangga dengan $n=22$.

\section{PEMBAHASAN}

Hasil penelitian menunjukkan state anxiety memiliki nilai lebih tinggi daripada trait anxiety. Hal ini menunjukkan bahwa orang tua yang mendampingi operasi anak merasakan state anxiety ketika anaknya sedang dioperasi. State anxiety ini dipicu oleh situasi yang sedang dihadapi oleh individu. State anxiety ini sangat dipengaruhi oleh trait anxiety, menunjukkan apabila trait anxiety tinggi, maka state anxiety akan tinggi. Hasil perhitungan menggunakan uji non-parametrik Mann Whitney pada perbedaan state dan trait anxiety yang dialami orang tua yang 
baru pertama kali mengalami anggota keluarga yang dioperasi dan orang tua yang sudah pernah mengalami operasi sebelumnya, diperoleh bahwa $\mathrm{H}_{0}$ diterima yang berarti tidak terdapat perbedaan yang signifikan pada kelompok dengan pengalaman pertama operasi dan kelompok dengan riwayat operasi sebelumnya. Hasil penelitian ini menunjukan pengalaman operasi tidak mempengaruhi kecemasan yang dialami oleh seseorang. Perbedaan yang tidak signifikan ini bisa disebabkan karena faktor-faktor lain penyebab dari kecemasan.

Kecemasan yang dirasakan oleh orang tua dari anakpenderita dapat disebabkan oleh beberapa faktor seperti usia, jenis kelamin, pendidikan, ekonomi, dan pekerjaan ditunjukan pada hasil penelitian. Pada penelitian ini, rata-rata operasi didampingi oleh kedua orang tua, namun ibu yang paling sering berada di lingkungan sekitar ruang tunggu operasi anak. Maka didapat data responden perempuan $(n=24)$ lebih banyak dibandingkan dengan laki-laki $(\mathrm{n}=6)$. Data tersebut memperlihatkan bahwa kecemasan perempuan atau ibu lebih tinggi dibandingkan dengan kecemasan laki-laki atau ayah. Orang tua akan lebih cemas saat situasi tertentu, terutama ibu, disebabkan karena ibu menghabiskan waktu lebih banyak bersama anak. Penelitian yang dilakukan oleh Varcoralis juga menyatakan bahwa kecemasan lebih sering dialami oleh perempuan dibandingkan dengan laki-laki. ${ }^{8}$ Jenis kelamin merupakan salah satu faktor internal yang memengaruhi kecemasan seseorang hal ini disebabkan karena perempuan lebih mempunyai perasaan yang sensitif. Faktor ini juga yang menyebabkan seorang perempuan/ ibu biasanya tetap berada di lingkungan yang dekat dengan ruangan operasi anak.

Faktor usia mempengaruhi kecemasan yang dialami oleh individu, dilihat dari kelompok usia 18 sampai 26 tahun memiliki hasil yang lebih tinggi jika dibandingkan dengan kelompok usia 2735 tahun dan kelompok usia 36-44 tahun. Hal ini didukung dengan pernyataan Varcoralis seseorang yang memiliki umur lebih muda akan lebih mudah mengalami kecemasan dibandingkan dengan yang lebih tua. ${ }^{8}$ Usia mempengaruhi emosi yang dirasakan oleh individu, karena semakin tua usia maka individu akan lebih baik dalam mengendalikan emosinya.

Status ekonomi dalam hal ini berupa penghasilan keluarga dalam sebulan memperlihatkan bahwa state anxiety tertinggi dengan penghasilan kurang dari Rp 500.000,00 dan terendah dengan penghasilan lebih dari Rp 2.000.000,00. Penelitian ini dilaksanakan di Instalasi Cleft Center RSGM FKG Unpad. Instalasi cleft center adalah tempat yayasan sosial bernama Yayasan Pembina Penderita Celah Bibir dan Langit-langit (YPPCBL) yang bergerak dibidang sosial medis dengan tujuan utama membantu penderita celah bibir dan langit-langit dari keluarga yang tidak mampu. Caranya adalah dengan membebaskan biaya operasi bagi penderita. Namun, dilihat dari hasil penelitian tersebut kecemasan yang dirasakan orang tua masih tinggi. Penelitian yang dilakukan Mariyam mengatakan hasil komunikasi interpersonal dengan orang tua yang menunggu anaknya dirawat mengatakan bahwa faktor ekonomi menjadi kendala utama ${ }^{8}$. Faktor ekonomi menjadi kendala utama disebabkan karena penghasilan yang rendah sehingga orang tua mencemaskan adanya pengeluaran yang tak terduga. Pengeluaran tak terduga ini salah satunya bisa disebabkan karena kebutuhan anak dan orang tua selama masa perawatan baik pre maupun post operasi, misalnya membeli susu anak, biaya makan keluarga, dan sebagainya.

Sebagian besar responden yaitu sebanyak 22 orang bekerja sebagai ibu rumah tangga memperlihatkan kecemasan yang tinggi dibandingkan dengan pekerjaan lainnya. Hal ini disebabkan karena dalam sehari-hari ibu yang paling sering bersama dengan anak dan mengetahui kondisi sehari-hari anak. Sejalan dengan penelitian yang dilakukan oleh Laharti ${ }^{9}$ yang mengatakan bahwa responden yang bekerja memiliki tingkat kecemasan 0.259 kali lebih rendah dibandingkan responden yang tidak bekerja. Anak penderita celah bibir dan langit-langit masih berada di usia batita (bawah tiga tahun). Mereka masih lebih banyak menghabiskan waktu di rumah. Sehingga orang tua dengan waktu yang dihabiskan lebih banyak di rumah dengan anak pada aktivitas sehari-harinya memiliki kedekatan yang lebih dan mengetahui kondisi anak dibandingkan dengan orang tua yang bekerja.

\section{SIMPULAN}

Simpulan penelitian ini adalah tidak terdapat perbedaan antara orang tua penderita celah bibir dan langit-langit yang belum dan telah dioperasi.

\section{DAFTAR PUSTAKA}

1. Faradina, N. 2016. Penerimaan Diri pada Orang Tua yang Memiliki Anak Berkebutuhan Khusus, eJournal Psikologi, 4 (4), 386-396.

2. World Health Organization. "Congenital malformations, deformations and chromosomal abnormalities (Q00-Q99) Cleft lip and cleft palate (Q35-Q37)". Avaliable at: http://apps.who.int/ classifications/apps/icd/icd10online2005/fr-icd. htm?gq35.htm, TW. 2010. Langman Embriologi Kedokteran, Alih bahasa Brahm U. Pendit, $10^{\text {th }}$ ed. Jakarta: EGC. 11 Januari 2018.

3. Salder, TW. 2010. Langman Embriologi Kedokteran, Alih bahasa Brahm U. Pendit, Ed. 10, Jakarta, EGC.

4. Boles, J. 2016. Preparing Children and Families for Procedures or Surgery. Pediatric Nursing, 42(3), 147-149. 
5. Digiulio, M., \& Jackson, D. 2014. Keperawatan Medikal Bedah. Yogyakarta, Rapha Publishing.

6. Shirley, PJ., Thompson, N., Kenward, M., \& Johnston, G., 2010, Parental anxiety before elective surgery in children, Nursing Journal, 53, 956-959.

7. Lubis, PY, Widianti, E., \& Amrullah, AA. 2014. Tingkat kecemasan orang tua dengan anak yang akan dioperasi. Fakultas Keperawatan Unpad, 2(3), 154-160.
8. Mariyam, AK. 2008. Faktor-faktor yang berhubungan dengan tingkat kecemasan orang tua terkait hospitalisasi anak usia toddler di BRSD RAA Soewonso Pati. Jurnal Keperawatan, 1(2), 38-56.

9. Fauziah, M., Novrianda, D., Hermalinda, 2016, Deskripsi Faktor-faktor Kecemasan Orang Tua pada Anak Pre Operasi di Ruang Bedah Anak RSUP DR. M. Djamil Padang, Ners Jurnal Keperawatan, 12 (2), 116-130. 